\title{
THE SIGNS OF SELF-REFLECTION IN BUILDING CHARACTER AMONG FIRST-YEAR PHYSICAL EDUCATION STUDENTS
}

\author{
Self-reflection among physical education students
}

\author{
ANNA BROJEK \\ The Josef Pilsudski University of Physical Education in Warsaw, \\ Faculty of Physical Education and Sportin Biała Podlaska \\ Mailing address: Anna Brojek, Faculty of Physical Education and Sport, 2 Akademicka Street, \\ 21-500 Biała Podlaska, tel.: +48 509111223, fax: +48 83 3428800, e-mail: ajbrojek@gmail.com
}

\begin{abstract}
Introduction. The concept of self-upbringing is identified with self-activity, building and shaping one's character, selfimprovement and self-realization. The aim of the research was to define the degree of self-upbringing of first year physical education students taking into consideration self-reflection on their behaviour. Material and methods. The method applied in the research was the diagnostic survey and the accompanying research technique was a questionnaire called 'The questionnaire of self-upbringing activity' designed by Tatarowicz. The survey was conducted in Academic Year 2008/2009 among 667 respondents in the eight state and non-state Polish universities. Results. The results show that students (57\%) tend to do self-reflection. The major reasons for this were failures in life and behaviour against prevailing norms. The majority of questioned $(72.0 \%)$ showed a high degree of complacency that was due to self-acceptance and the state of feeling good in the accepted community. The participants who declared a lower degree of complacency claimed that it was due to different kinds of failures, a sense of having many faults and the awareness of making mistakes. On the hole, the participants did not feel different or distinct in regard to other people - more than $70.0 \%$. Those that have such a feeling claim that the differences concern mainly the look and the way of behaving. Conclusions. An important role in searching the specific ways of coping with negative sides of life plays constant education and the state of self-upbringing which influences the awareness and the development of an individual.
\end{abstract}

Key words: students, physical education, self-upbringing, self-reflection

\section{Introduction}

Contemporary humans have to search for the constructive ways of coping with negative aspects of life. One has to face a fast pace of life, civilized diseases, environmental pollution, fear for constant increase in schools' and employees' requirements, social changes, the emptiness of religious life, the domination of an authoritarian form of education, religion and human relationships. One should more frequently learn that one of the ways of coping with challenges of the contemporary world is constant learning, building human relationships, a need for being close to nature and protecting it [1].

Human development depends on the degree of awareness of directing this development and it can be guided by either by a guardian or by oneself since it is one who has potential possibility to guide one's behavior and development [2]. The crowning achievement of upbringing is to develop self-upbringing in a child which is a reliable yardstick for effective upbringing. It intends to arise a need for self-upbringing, namely a need for versatile developing one's character. Self-upbringing determines who a person will be in the future and whether a person will be able to obey the instilled values. It can be said that parents succeed in parental upbringing if a child develops self-upbringing and is responsible for one's behaviour and at the same time one bears in mind religious, moral and social values. This is a way to shape one's moral and religious values and mould one's personality. Achieving fully mature humanity is a constant stimulus for moulding oneself [3].

Broadly speaking, upbringing can be defined as any impact upon a person. It can be the family, community or school influences either intended or not. The accidental influences are also of great importance since it helps to mould one's personality. In specific terms, upbringing is intended and deliberate impact on a person. There is a specific aim behind it and it is carried out in a specific situation. This specific aim is human versatile development and preparing one to live according an accepted pattern. This life pattern is determined by important values of the given society in which a person was brought-up [4].

From traditional point of view, self-upbringing aimed at forming positive traits and eliminating negative inclinations. The contemporary definitions say that upbringing is an intended intervention in the process of self striving for the tasks realization. Building one's character is not only an elimination of negative traits and developing positive ones but it is also the realization of own potential possibilities. 
The self-upbringing is an ambiguous term. It is identified with self-activity, building and shaping one's character, self-improvement and self-realization. A person has to work upon forming one's point of view, one's behaviour, one's traits and personality and at the same time one has to obey accepted criteria, aims and ideals. At the certain stage of human development a person on one's own starts to define aims that need to be achieved, chooses appropriate methods, determines core values of human life and not only sets the tasks and requirements but also tries to face challenges [6].

The purpose of the survey was to define the degree of self-upbringing of first year physical education students taking into consideration self-reflection on their behaviour.

\section{Material and methods}

The method applied in the research was a diagnostic survey and the accompanying research technique was a questionnaire called 'The questionnaire of self-upbringing activity' designed by Tatarowicz [7]. The survey was conducted in Academic Year 2008/2009 among 667 respondents in the eight state and non-state Polish universities.

\section{Results}

Self-reflection is a vital element of upbringing. The majority of people attempt to involve themselves in selfreflection and try to change themselves, however, every person makes different changes in different aspects of life. The results of the research show that more than a half of students $(56.8 \%)$ often and very often involve themselves in self-reflection on their behavior. The rest of respondents did not involve themselves in self-reflection so often.

A person makes an evaluation of one's behaviour taking into account a previously accepted image of oneself and the bahaviour model. The degree of acceptance of oneself was defined as 'complacency' and most of the questioned $(72.6 \%)$ admit they accept themselves fully. The reason for complacency was the acceptance of community and it was stated by $39.0 \%$ of respondents. Other significant reasons for complacency concerned self-acceptance and satisfaction from a consistent attempt to achieve a goal. Students who did not feel full complacency claim it happens due to their failures in life and they represent $27.8 \%$ of all respondents. The interviewers also put it down to the fact that they have many shortcomings and they are aware of making mistakes. The least important reasons for the degree of complacency were family problems and the fact of being unable to deal with difficult situations (Tab. 1).
Table 1. Frequency of self-reflection and the degree of complacency among respondents

\begin{tabular}{|l|l|r|r|}
\hline \multirow{4}{*}{ Specification } & \multicolumn{1}{|c|}{ Answer } & N & \multicolumn{1}{c|}{$\%$} \\
\hline \multirow{3}{*}{$\begin{array}{l}\text { Frequency } \\
\text { of self-reflection }\end{array}$} & often & 358 & 56.8 \\
\cline { 2 - 4 } & sometimes & 301 & 41.9 \\
\cline { 2 - 4 } & never & 8 & 1.2 \\
\hline \multirow{3}{*}{$\begin{array}{l}\text { Degree } \\
\text { of complacency }\end{array}$} & full & 455 & 72.5 \\
\cline { 2 - 4 } & partial & 189 & 26.9 \\
\cline { 2 - 4 } & none & 23 & 0.5 \\
\hline \multirow{3}{*}{$\begin{array}{l}\text { Reasons } \\
\text { for complacency }\end{array}$} & community acceptance & 261 & 39.0 \\
\cline { 2 - 4 } & self-acceptance & 160 & 24.0 \\
\cline { 2 - 4 } & an attempt to achieve a goal & 153 & 23.1 \\
\cline { 2 - 4 } & having assets & 93 & 13.8 \\
\hline \multirow{4}{*}{$\begin{array}{l}\text { Reasons } \\
\text { for dissatisfaction } \\
\text { with oneself }\end{array}$} & laziness & 53 & 7.8 \\
\cline { 2 - 4 } & life failures & 187 & 27.8 \\
\cline { 2 - 4 } & inability to deal with life & 113 & 6.4 \\
\cline { 2 - 4 } & difficult situations & 107 & 17.2 \\
\cline { 2 - 4 } & awarness of making mistakes & 140 & 20.7 \\
\cline { 2 - 4 } & awarness of faults & & 15.7 \\
\cline { 2 - 4 } & others & & \\
\hline
\end{tabular}

Having analyzed the research materials concerning self-reflection on one's distinctiveness it can be said that most of physical education students $(71.8 \%)$ did not feel distinct in regard to other people. They assert that they do not differ much from other students. Those students who have seen their distinctiveness revealed the reasons for selfreflection. The major reason for self-reflection among the most of the students were different failures in life. They also admit that behavior against norms was the reason for doing self-reflection. The least important factors inducing to self-reflection were problems with sport achievements and depression. Such a result seems to be logical due to the characteristics of the studies. The rest of the factors were also believed not to be important (Tab. 2).

Table 2. Self-reflection on distinctiveness among students

\begin{tabular}{|l|l|r|r|}
\hline \multicolumn{1}{|c|}{ Specification } & \multicolumn{1}{|c|}{ Answer } & N & \multicolumn{1}{c|}{$\%$} \\
\hline \multirow{2}{*}{ Doing self-reflection } & I see my distinctiveness & 202 & 28.8 \\
\cline { 2 - 4 } & I don't see my distinctiveness & 465 & 71.8 \\
\hline \multirow{5}{*}{$\begin{array}{l}\text { Circumstances inducing } \\
\text { to self-reflection }\end{array}$} & behaviour against norms & 147 & 22.0 \\
\cline { 2 - 4 } & failures in life & 290 & 43.5 \\
\cline { 2 - 4 } & difficult situations & 67 & 10.2 \\
\cline { 2 - 4 } & depression & 10 & 1.8 \\
\cline { 2 - 4 } & sport achievement failure & 20 & 2.4 \\
\cline { 2 - 4 } & others & 133 & 19.8 \\
\hline
\end{tabular}

The research material concerning the attitude towards students' distinctiveness showed that $74.7 \%$ of respondents argue they are satisfied with their individuality. This distinctiveness mainly concerned differences in the look and the ways of behaving. The next vital factor defining students distinctiveness is the complete different system of values (Tab. 3). 
Table 3. Students' attitude towards their distinctiveness

\begin{tabular}{|l|l|r|r|}
\hline \multicolumn{1}{|c|}{ Specification } & \multicolumn{1}{|c|}{ Answer } & N & \% \\
\hline $\begin{array}{l}\text { Attitude towards } \\
\text { distinctiveness }\end{array}$ & I'm satisfied & 501 & 74.7 \\
\cline { 2 - 4 } & I'm not satisfied & 166 & 25.2 \\
\hline \multirow{2}{*}{$\begin{array}{l}\text { Characteristics } \\
\text { of my distinctiveness }\end{array}$} & different attitude towards values & 146 & 22.0 \\
\cline { 2 - 4 } & look and behaviour & 453 & 65.3 \\
\cline { 2 - 4 } & different point of view & 86 & 12.6 \\
\hline
\end{tabular}

The statements that show students' viewing of their distinctiveness are: I'm an optimist and I'm happy about even the smallest things; The world would be boring if everyone was the same; Every person is unique and differs from others; I have my own point of view and I'm not afraid to defend my view; Every person should have one's rules.

\section{Discussion}

One of the basic needs making a person cultured is a need for self-realization which aims at actualization of one's needs and potential possibilities. Self-upbringing is then intentional strive for making personality changes without any exterior pressure. It is the process of learning by oneself depending on a person involved in it and requiring persistence in achieving a goal [8].

Taking into consideration this specific context, the signs of self-reflection among students seem to function well. The majority of students were involved in selfreflection on their behaviour which contributed to being satisfied with their activities. The opinions mentioned above confirmed the results of the previous research carried out by Dąbrowska [9], Krajski [10] and Lewandowski [8]. The circumstances for self-reflection among respondents are various. Students of physical education put it down to numerous failures in life and the situations when they behaved against accepted norms. Żylicz [11], on the other hand, obtained slightly different results while carrying out similar research. According to Żylicz, the most important reasons for involving oneself in self-reflection are difficult life situations, depression and didactic failures. The main reason for complacency among respondents was the fact that students accepted their personality, felt happy and accepted by the community. Stepulak [12] and Ronikier [13] came to similar conclusions. As for Turner [14], he achieved a bit different results since he claims that a key reason for complacency is students' belief in having many assets and consistent achievement of goals. When compared with other people, students of physical education were able to see clear distinctiveness concerning their individuality. This distinctiveness concerned mainly differences in the look and the ways of behaving which contributed to their complacency. Others factors influencing the sense of distinctiveness were discussed by Łapińska [15]. According to Łapińska, these differences resulted from the complete different system of values and students' point of view.

\section{Conclusion}

An important role in searching the specific ways of coping with negative sides of life plays constant education and the state of self-upbringing which influences the awareness and the development of an individual.

\section{Acknowledgements}

The research was accomplished within the framework of research project of Faculty of Physical Education and Sport in Biała Podlaska, Josef Pilsudski University of Physical Education in Warsaw - BW.III/10 - financed by the Ministry of Science and Higher Education.

\section{Literature}

1. Zieliński, P. (2001). Reflections after Teaching of Relaxingconcentration Methods to Pedagogy Students for Ten Years. Yearbook of alternative education. Łódź: Wydawnictwo Naukowe Wyższej Szkoły Kupieckiej. [in Polish]

2. Schoenebeck, H. (1994). Anti-pedagogy - to Be and Support. Warsaw: Wydawnictwo J. Santorski. [in Polish]

3. Skreczko, A. (2003). Self-upbringing. Czas Mitosierdzia 12. [in Polish]

4. Płonka, M. (2004). The essesnse of self-upbringing. Wychowawca 11. [in Polish]

5. Bochenek, A. \& Burzyński W. (2004). Self - educational activity as an element of axiological aspects of sport. In J. Kosiewicz Axiological Dimensions of Sport - Practical Aspects. Rzeszów : University of Rzeszów.

6. Krajski, S. (1998). Foundations of Self-upbringing. Warsaw: Akademickie Stowarzyszenie Katolickie.

7. Tatarowicz, J. (1988). Religiosity of Youth and Their Sense of Life and Work on Themselves. Warsaw: Wyd. Akademii Nauk Społecznych. [in Polish]

8. Lewandowski, K. (2000). Self-upbringing as fruit of activity and contemplation. Trzeźzymi bądźcie 4. [in Polish]

9. Dąbrowska, A. (1993). Man-creating values and socializing functions of sport. In Z. Żukowska (Ed.), Towards Identity of Pedagogy of Physical Culture. Warsaw: PTNKF. [in Polish]

10. Krajski, S. (1998). Foundations of Self-upbringing. Warsaw: Akademickie Stowarzyszenie Katolickie „Soli Deo". [in Polish]

11. Żylicz, P. (1996). Self-actualization and Moral Integration. Warsaw: Fundacja ATK. [in Polish]

12. Stepulak, M. (2001). Selected Aspects of Psychology of Personality. Lublin: Towarzystwo Naukowe Katolickiego Uniwersytetu Lubelskiego. [in Polish]

13. Ronikier, A. (2004). Physical activity in health prevention. In J. Czerwiński (Ed.), Physical Activity as a Need of Creative Life. Olsztyn: Olsztyńska Szkoła Wyższa. [in Polish] 
14. Turner, J.S. \& Helms D.B. (1999). Human development. Warsaw: Wydawnictwa Szkolne i Pedagogiczne. [in Polish]

15. Łapińska, D. (2004). Situation of young people - selfupbringing. http:/WWW. isr. org. pl./ISR/ studium 2004/ samowychowanie. Htm.

Submitted: March 15, 2010

Accepted: April 22, 2010 